\title{
Anaesthetics for General Anaesthesia in Growing Pigs
}

\author{
By H. Henrikson, M. Jensen-Waern and G. Nyman
}

Department of Medicine and Surgery, Faculty of Veterinary Medicine, Swedish University of Agricultural Sciences, Uppsala, Sweden.

\begin{abstract}
Henrikson, H., M. Jensen-Waern and G. Nyman: Anaesthetics for general anaesthesia in growing pigs. Acta vet. scand. 1995, 36, 401-411. - A comparison was made between different anaesthetics for general anaesthesia in growing pigs, with focus on minor surgery under field conditions and for experiments in clinical research. Healthy crossbreed pigs (HampshirexYorkshire $\times$ Swedish Landrace) weighing 20-45 kg were used. The anaesthetics combinations compared were 1) azaperone plus metomidate (AM), 2) Zoletil ${ }^{\circledR}$ (zolazepam + tiletamine) plus xylazine (ZX), and 3) Zoletil ${ }^{\circledR}$ plus xylazine plus ketamine (ZXK). Parameters measured were: heart rate, respiratory rate, blood pressure, body temperature, and depth of analgesia (pin-prick). Minor surgery was performed to test the reliability of the "pin-prick" tests.

It was clearly shown that AM produces anaesthesia with good cardiovascular stability and is a drug combination that is suitable for minor surgery. ZX also produces a good anaesthesia characterized by reliable and rapid induction. Good cardiovascular function is maintained, and the laryngeal relaxation makes intubation possible. These characteristics are very useful in a laboratory environment, as easy handling to avoid stress is necessary for research. Although it is difficult to evaluate the quality of analgesia from this study, it is concluded that ZX did not provide a superior anasthesia and analgesia compared to AM in crossbreed pigs. However, these drugs are too expensive for regular use in ambulatory practice. The effects of ZXK resemble those of ZX, but the ZXK-drug combination has no anaesthetic advantages and is more laborious to work with.
\end{abstract}

azaperone; metomidate; Zoletil $^{\circledR}$, xylazine; ketamine.

\section{Introduction}

General anaesthesia in growing swine is mainly used for surgery under field conditions and in clinical research. Most surgical procedures on pigs, such as hernias, are performed in the growing period. Surgery under field conditions requires an anaesthetic drug which can be given either intramuscularly (im) or intraperitoneally (ip), since intravenous (iv) drug administration may be difficult when skilled assistance is not available. Neither is advanced monitoring nor the use of inhalation agents feasible under field conditions. Therefore, drugs used for anaesthesia in ambulatory practice should be easy to administer, allow smooth induction, have a wide margin of safety, and provide sufficient analgesia for surgery. Further, they should permit rapid recovery and be economically favourable. Taking all these requirements into consideration, the choice of anaesthetic drug is difficult for many veterinarians.

The pig is an excellent experimental animal in comparative physiology and has thus been 
widely used in clinical research (Beglinger et al. 1975, Hastings et al. 1982). The anaesthetics used for laboratory experiments need in some respects to have qualities different from those to be used in veterinary practice. To allow calm induction without elevation of stress hormones and a negative influence on cardiopulmonary function, quick intramuscular administration with a small volume would appear to be less stressful than the restraint required for iv injection. Ideally, the anaesthetic should give rapid, smooth induction and laryngeal relaxation sufficient for intubation. Commonly, the anaesthesia is maintained with either inhalation or intravenous injection or infusion.

Because of the consumers' demand, most pigs in the Nordic countries used to be castrated. The drug combination azaperone and metomidate (AM) has been widely used for castration of male pigs with hernias. Although this method produces light general anaesthesia which can be combined with local analgesia, it is safe for minor surgery under field conditions (Raekallio 1991). Azaperone is administered intramuscularly, followed by an ip or iv injection of metomidate.

The dissociative anaesthesia has been widely used in most mammals, including man. Ketamine, which is the most common dissociative anaesthetic, has several side effects in humans such as hallucination, catalepsy and excitement. Fear seems to occur in animals (Muir et al. 1989). To minimise these negative effects, the dissociative agent requires good sedation, and an $\alpha_{2}$-adrenoceptor agonist has therefore been used prior to ketamine in pigs. Recently, in an attempt to find suitable anaesthetic alternatives for minor surgery in growing pigs, Henrikson (1992) evaluated various types of general anaesthesia and found that anaesthesia with ketamine in combination with various sedatives did not provide sufficient analgesia.
Further, it is rather expensive for use in farm animals.

A new and promising drug combination, Zoletil $^{\circledR}$ and xylazine (ZX), is available for intramuscular use in growing swine. Zoletil ${ }^{\circledR}$ consists of the benzodiazepine zolazepam and the cyclohexamine tiletamine. Thurmon et al. (1988a, 1988b) and Braun (1993) reported that $\mathrm{ZX}$ provided both effective and safe induction and maintenance of general anaesthesia in swine. Further, addition of ketamine to the $\mathrm{ZX}$ combination, (ZXK), has been reported to produce excellent induction of anaesthesia in potbellied pigs (Ko et al. 1992).

The present study was undertaken to evaluate these new anaesthetic alternatives, $\mathrm{ZX}$ and ZXK, in comparison with AM for short-term anaesthesia in growing pigs.

\section{Materials and methods}

Animals

Twenty-seven healthy crossbreed pigs (Hampshire $\times$ Yorkshire $\times$ Swedish Landrace) weighing between $20-45 \mathrm{~kg}$ were used. All of them originated from a herd with a good health status, under the supervision of swine specialists from the Faculty of Veterinary Medicine. They were housed in conventional pens at the Department of Medicine and Surgery and fed on a standard feeding scale with a barley-based diet. Every pig was anaesthetized only once with each drug combination, but could be used for testing a different anaesthetic combination later on during the experimental period. The period between 2 drug-tests was at least $72 \mathrm{~h}$.

\section{Experimental design}

The experimental design was approved by the Ethical Committee for Animal Experiments, Uppsala, Sweden. The pigs were divided into 3 experimental groups, as described below. 
All animals were given atropine $0.05 \mathrm{mg} / \mathrm{kg}$ im as premedication to avoid salivation and laryngeal spasm.

1) Eight pigs were anaesthetized with azaperone (Stresnil ${ }^{\circledR} 40 \mathrm{mg} / \mathrm{ml}$, Janssen Pharmaceutica, Beerse, Belgium) in a dose of 2 $\mathrm{mg} / \mathrm{kg}$ body weight (bw) im followed directly by metomidate (Hypnodil $^{\circledR} 50$ $\mathrm{mg} / \mathrm{ml}$, Janssen Pharmaceutica, Beerse, Belgium) in a dose of $10 \mathrm{mg} / \mathrm{kg}$ bw ip.

2) Twelve pigs were anesthetized with a combination of xylazine (Rompun ${ }^{\circledR} 20 \mathrm{mg} / \mathrm{ml}$, Bayer AG, Monheim, Germany) in a dose of $2 \mathrm{mg} / \mathrm{kg}$ im followed by Zoletil ${ }^{\circledR} 6$ $\mathrm{mg} / \mathrm{kg}$, im. Zoletil ${ }^{\circledR}(100 \mathrm{mg} / \mathrm{ml}$, Virbac, Carros, France) is a mixture of tiletamine $(50 \mathrm{mg} / \mathrm{ml})$ and zolazepam $(50 \mathrm{mg} / \mathrm{ml})$. The ZX mixture given per kg bw consisted of $3 \mathrm{mg}$ tiletamine, $3 \mathrm{mg}$ zolazepam and 2 mg xylazine.

3) Seven animals were used in this group and were anaesthetized with Zoletil ${ }^{\circledR}$, xylazine and ketamine. The ZXK mixture is made by adding $2.5 \mathrm{ml}$ ketamine (Vetalar ${ }^{\circledR} 100$ $\mathrm{mg} / \mathrm{ml}$, Parke-Davis, New Jersey, USA) and $2.5 \mathrm{ml}$ xylazine (Rompun ${ }^{\circledR} 100 \mathrm{mg} / \mathrm{ml}$ ) to Zoletil ${ }^{\circledR}$ powder ( $5 \mathrm{ml}$ vial). The resulting ZXK mixture consists of $250 \mathrm{mg}$ tiletamine, $250 \mathrm{mg}$ zolazepam, $250 \mathrm{mg}$ xylazine and $250 \mathrm{mg}$ ketamine. This mixture was given intramuscularly at a dose of 0.1 $\mathrm{ml} / 4.5 \mathrm{~kg}$ bw. The ZXK mixture given per $\mathrm{kg}$ bw consisted of $0.55 \mathrm{mg}$ tiletamine, 0.55 $\mathrm{mg}$ zolazepam, $0.55 \mathrm{mg}$ xylazine and 0.55 mg ketamine.

\section{Anaesthetic parameters}

All pigs were examined 5, 10, 15, 20, 25, 30, 35, 45 and 60 min after recumbency, and the following parameters were chosen to reflect the cardiorespiratory function and the quality of the anaesthesia. The respiratory rate was measured by observing the costo-abdominal movements. Heart rate and mean arterial blood pressure were monitored non-invasively with an oscillometric technique (BP 103, Nippon Collin Co. Ltd, Japan) with cuffs no. 13 , width $5 \mathrm{~cm}$, for pigs below $25 \mathrm{~kg}$ and no.14, width $7 \mathrm{~cm}$, for larger pigs. The cuffs were placed above the carpal joint. The noninvasive bloodpressure measurement was in good agreement with an invasive method carried out in 8 pigs. The invasive pressure was measured through an indwelling catheter in the auricular or saphenous artery connected via a fluid-filled line to a pressure transducer (Baxter, Deerfield, IL, USA ) and was monitored on a pressure monitor (Sirecust 730, Siemens AB, Stockholm, Sweden). Rectal temperature was measured with an electronic thermometer. The reflexes tested were the corneal reflex, by a gentle touch with a pen, and pin-prick, by pinching with forceps in the coronary band, tail and skin. The criteria proposed by Thurmon et al. (1988a) were used to evaluate anaesthetic induction, recovery, and analgesia and are shown in Table 1. However, the results from the present study are presented as induction, anaesthesia including muscle relaxantia, analgesia, and recovery.

To relate the body movements following the pin-prick test to signs of pain from surgery for umbilical hernias or inguinal hernias, operations were performed on 4 pigs anaesthetized with $\mathrm{AM}$ and on 4 pigs anaesthetized with ZX. In an attempt to interpret response to pain, blood pressure was measured invasively to find out if body movements were correlated to a simultaneous rise in blood pressure was interpreted as response to pain. Surgery was not performed on any pig in group 3 , because of the poor quality of analgesia as measured by the pin-prick test.

\section{Intubation}

All the animals undergoing surgery were intu- 
Table 1. Criteria used to evaluate anaesthetic induction, anaesthesia \& analgesia and recovery (Thurmon et al. 1988a).

\begin{tabular}{|c|c|c|c|}
\hline & \multicolumn{3}{|c|}{ Drug effect } \\
\hline & Good & Fair & Poor \\
\hline Anaesthetic induction & $\begin{array}{l}\text { No outward signs of } \\
\text { excitement; rapidly } \\
\text { assumes sternal } \\
\text { recumbency and easily } \\
\text { accepts tracheal } \\
\text { intubation. }\end{array}$ & $\begin{array}{l}\text { Mild signs of } \\
\text { excitement, continuous } \\
\text { movement, numerous } \\
\text { attempts to arise } \\
\text { immediately after } \\
\text { assuming recumbency, } \\
\text { poor muscle relaxation, } \\
\text { responsive to tracheal } \\
\text { intubation. }\end{array}$ & $\begin{array}{l}\text { Hyperkinesis, } \\
\text { obvious signs of } \\
\text { excitement, does not } \\
\text { become recumbent or } \\
\text { does so only briefly, } \\
\text { poor muscle relaxation. }\end{array}$ \\
\hline Anaesthesia \& Analgesia & $\begin{array}{l}\text { No response to pin } \\
\text { prick. }\end{array}$ & $\begin{array}{l}\text { Mild response to pin } \\
\text { prick (mild muscle } \\
\text { fasciculations only). }\end{array}$ & $\begin{array}{l}\text { Very responsive to pin } \\
\text { prick (moderate to } \\
\text { severe muscle } \\
\text { fasciculations). }\end{array}$ \\
\hline Reco ery & $\begin{array}{l}\text { Pig assumes sternal } \\
\text { position with little or } \\
\text { no struggling; stands } \\
\text { and walks in a } \\
\text { reasonable amount } \\
\text { of time. }\end{array}$ & $\begin{array}{l}\text { Some struggling, } \\
\text { requires assistance to } \\
\text { stand. }\end{array}$ & $\begin{array}{l}\text { Prolonged struggling, } \\
\text { unable to stand even } \\
\text { with assistance. }\end{array}$ \\
\hline
\end{tabular}

bated with the guide-wire technique described by Thurmon \& Benson (1987).

\section{Statistical analyses}

All data are presented as mean values and standard error of the mean (SEM) unless otherwise indicated. Analysis of variance for repeated measures was used to examine differences in respiratory rate, heart rate, and blood pressure over time. If ANOVA indicated a significant $(\mathrm{p}<0.05)$ difference, further analysis was carried out using the Wilcoxon signedrank test to compare the values obtained during anaesthesia with the initial values. Also, the different methods of anaesthesia were compared at each time-point by the Wilcoxon rank-sum test.

\section{Results}

The animals remained healthy throughout the experimental period. All the pigs were tolerant to the different drugs included in the anaesthetic experiments, and no side-effects were observed.

General anaesthesia with azaperone and metomidate

This drug combination fulfils the requirements for anaesthesia for minor surgery including intubation. The 8 pigs (group 1) assumed recumbency within 150 to $240 \mathrm{sec}$. As shown in Table 2, the anaesthetic induction and recovery were of good quality in all pigs. The sternal position was resumed after $65-120$ min. According to the criteria for analgesia suggested by Thurmon et al. (1988), the analgesia was fair in 6 pigs and poor in 2 animals 
Table 2. The number of pigs were characterized as good, fair and poor responders to the various anaesthetic drugs in this study. The results were graded according to Table 1.

\begin{tabular}{|c|c|c|c|c|}
\hline & & \multicolumn{3}{|c|}{ Drug effect } \\
\hline & & Good & Fair & Poor \\
\hline Azaperone + metomidate & Anaesthetic induction & 8 & & \\
\hline (group 1) & Anaesthesia \& Analgesia & & 6 & 2 \\
\hline $\mathrm{n}=8$ & Recovery & 8 & & \\
\hline Zoletil + xylazine & Anaesthetic induction & 12 & & \\
\hline (group 2) & Anaesthesia \& Analgesia & 2 & 6 & 4 \\
\hline $\mathrm{n}=12$ & Recovery & 12 & & \\
\hline Zoletil + xylazine + ketamine & Anaesthetic induction & 2 & 5 & \\
\hline (group 3) & Anaesthesia \& Analgesia & & 1 & 6 \\
\hline $\mathrm{n}=7$ & Recovery & 7 & & \\
\hline
\end{tabular}

(Table 2). The respiratory rate was stable, at about 20 breaths per min (Fig. 1). A slight decrease in heart rate was noted with time during anaesthesia, from a mean of 100 beats per min initially to a mean of 85 beats per min after $60 \mathrm{~min}$ (Fig. 2). The slight body movements in response to pain in the additional 4 pigs studied under surgery did not result in any simultanous rise in blood pressure. The mean arterial blood pressure was stable during anaesthesia, at about $70 \mathrm{~mm} \mathrm{Hg}$ (Fig 3). In all pigs, the rectal temperature fell by $1.5-3^{\circ} \mathrm{C}$ as measured after $60 \mathrm{~min}$ of anaesthesia. The pigs showed good muscle relaxation during surgery. The duration of anaesthesia was sufficient, and no further administration of the drugs was required during surgery for inguinal or umbilical hernias.

General anaesthesia with Zoletil ${ }^{\circledR}$ and xylazine This group showed the smoothest and most reliable induction of anaesthesia. After injection of ZX, all pigs were recumbent within 90 to $150 \mathrm{sec}$ and possible to intubate. The anaesthetic induction and recovery were good in all pigs. The pigs were back in the sternal position after 65-90 min. Within this group, all pigs had good muscle relaxation, but only 2 pigs showed good analgesia (Table 2). The respiratory rate was stable at about 65 breaths per min (Fig.1). A decrease in heart rate with time, from a mean of 150 beats per min to a mean of 100 beats per min occurred during anaesthesia (Fig. 2). The body movements, as a result of pin-prick or surgery, did not result in any rise in blood pressure. The mean arterial blood pressure was stable at about $75 \mathrm{~mm}$ $\mathrm{Hg}$ (Fig. 3). A fall in temperature of about $2^{\circ} \mathrm{C}$ was observed in all the animals after $60 \mathrm{~min}$ of anaesthesia.

General anaesthesia with Zoletil $^{\circledR}, x$ xylazine and ketamine

In this group, all pigs assumed recumbency within 90 to $150 \mathrm{sec}$. In the majority of the pigs, the anaesthetic induction was fair, and only in 2 animals was it considered good (Table 2). Recovery was good in all pigs and they were in the sternal position no later than 40-45 min after induction. Only in 1 pig was the analgesia of fair quality, while the rest of the pigs showed analgesia of poor quality. The analgesia in this group was too poor for surgery. The respiratory rate was significantly lower in the ZXK group than at the ZX group in the first 6 measurement times. No signifi- 


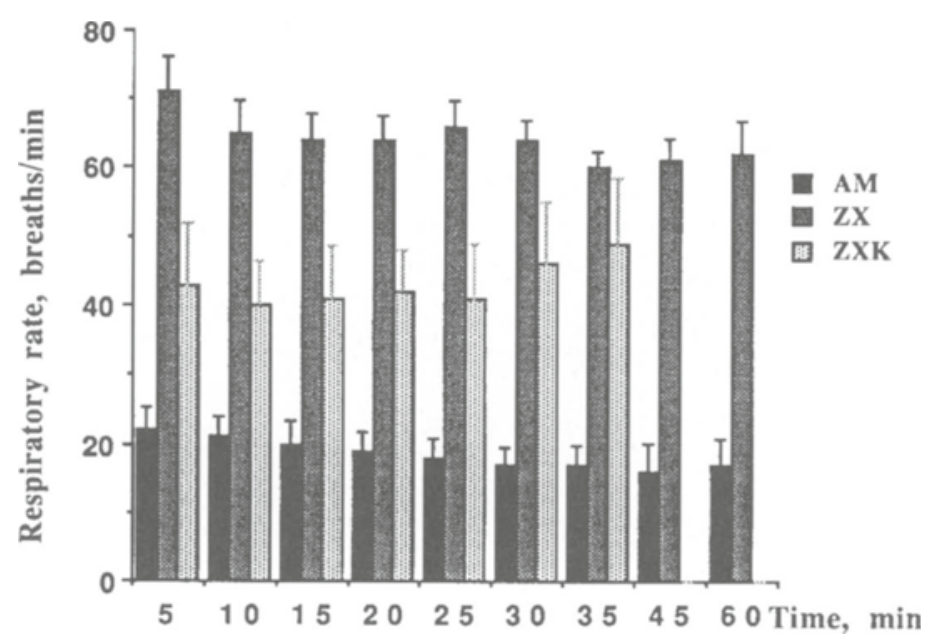

Figure 1. Respiratory rate examined 5, 10, 15, 20, 25, 30, 35, 45 and $60 \mathrm{~min}$ after recumbency. The anaesthesia was induced with azaperone and metomidate (AM), Zoletil ${ }^{\circledR}$ and xylazine (ZX) and Zoletil ${ }^{\circledR}$, xylazine and ketamine (ZXK). The number of pigs was 8,12 and 7 , respectively.

cant difference was noted at the last measurement time, as the ZXK animals were close to recovery and the respiratory rate was increasing (Fig. 1). The heart rate pattern was similar to that in group 2 (Fig.2). As shown in Fig. 3, the blood pressure was stable at about $75 \mathrm{~mm}$ $\mathrm{Hg}$ throughout the anaesthesia. A fall in temperature occurred in this group also, amounting to $0.5-1.2^{\circ} \mathrm{C}$ after $25 \mathrm{~min}$ of anaesthesia.

\section{Discussion}

All pigs in the present study, irrespective of the choice of anaesthetic drugs, were good subjects for general anaesthesia. Even though pigs are easily mentally stressed, as reflected in their hormonal and metabolic responses (Häggendahl et al. 1988, Jensen-Waern \& Nyberg 1993), both the induction of general anaesthesia and the recovery were smooth and calm (Table 2).

\section{Administration of anaesthetics}

General anaesthesia is an alternative to local anaesthesia, even for minor surgery, since the restrained pig will create a lot of struggling and squeals. A number of methods for anaesthesia in the growing pig have been used over the years. Inhalation with trichloroethylene, ether or chloroform through an open face mask was previously used quite commonly in field practice. Although these inhalants worked very well from an anaesthetic point of view, they are rarely used today because of the strong occupational health hazards involved in the use of volatile agents without waste gas scavenging. Today, inhalation anaesthetics are used under research conditions where sophisticated equipment is available and the question of expense does not limit the choice of anaesthetic technique. However, caution must be observed in stresssusceptible pigs with the genotype $\mathrm{Hal}^{\mathrm{n}} \mathrm{Hal}^{\mathrm{n}}$ (Webb et al. 1982), since the pharmacogenetic 


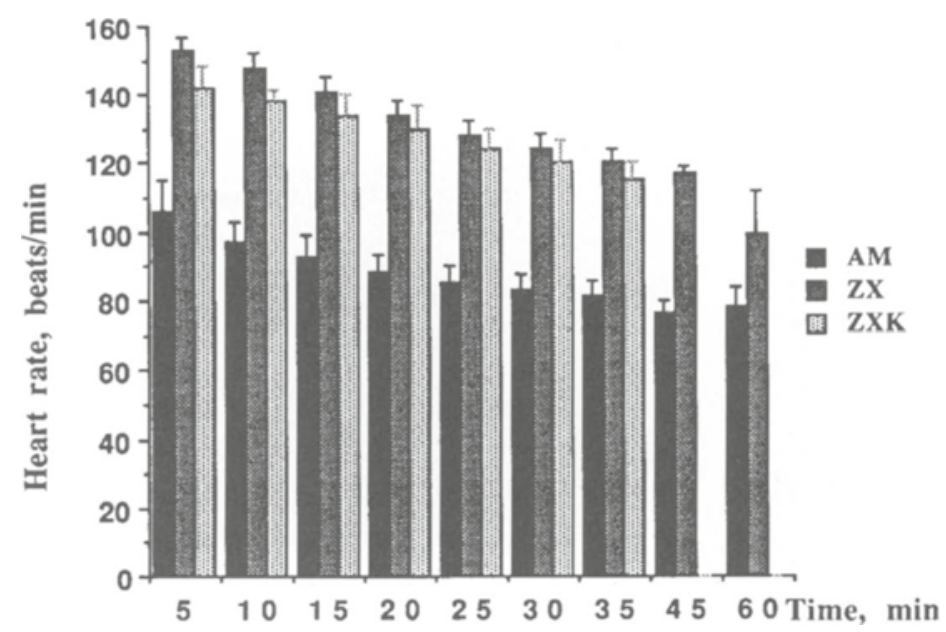

Figure 2. Heart rate monitored in 3 experimental groups of pigs 5, 10, 15, 20, 25, 30, 35, 45 and 60 min after recumbency. For abbreviations see Fig. 1.

disorder malignant hyperthermia may be triggered by inhalation anaesthetics such as halothane (Eikelenboom \& Minkema 1974).

Injectable anaesthetic agents may be given by the intravenous, intraperitoneal or intramuscular route. Although an excellent way of inducing general anaesthesia in the pig, a disadvantage of intravenous administration is the difficulty in venepuncture and injection into the auricular vein, especially if the animal is small and struggles. Also, tissue necrosis of the ear may occur after intravenous injection of anaesthetic agents. Barbiturate anaesthetics, such as pentobarbitone sodium, have been widely used for general anaesthesia in pigs, administered either intraperitoneally or intravenously. Even though these drugs are less expensive than most anaesthetic agents, disadvantages such as respiratory depression and prolonged recovery may limit their usefulness for field anaesthesia (Hall \& Clarke 1991). Intraperitoneal injection may be cumber- some, since it requires skilful handling of the pig and technical assistance. Moreover, improper administration into fat, urinary bladder, intestines or other organs will cause an unpredictable uptake of the drug (Hall \& Clarke 1983). Problems of irregular induction of anaesthesia often arise from the ability of the pig to use adipose tissue as a depot for anaesthetics, and complications such as peritonitis have also been reported after intraperitoneal injections (Hall \& Clarke 1991). Quick and smooth intramuscular administration of the anaesthetic agent without a need for restraining the animal would be an ideal method of induction.

General anaesthesia with injectable anaesthetics

Although the present study showed that both AM and ZX gave excellent induction (Table $2)$, the latter combination is to be preferred because of its shorter induction time, 90-150 


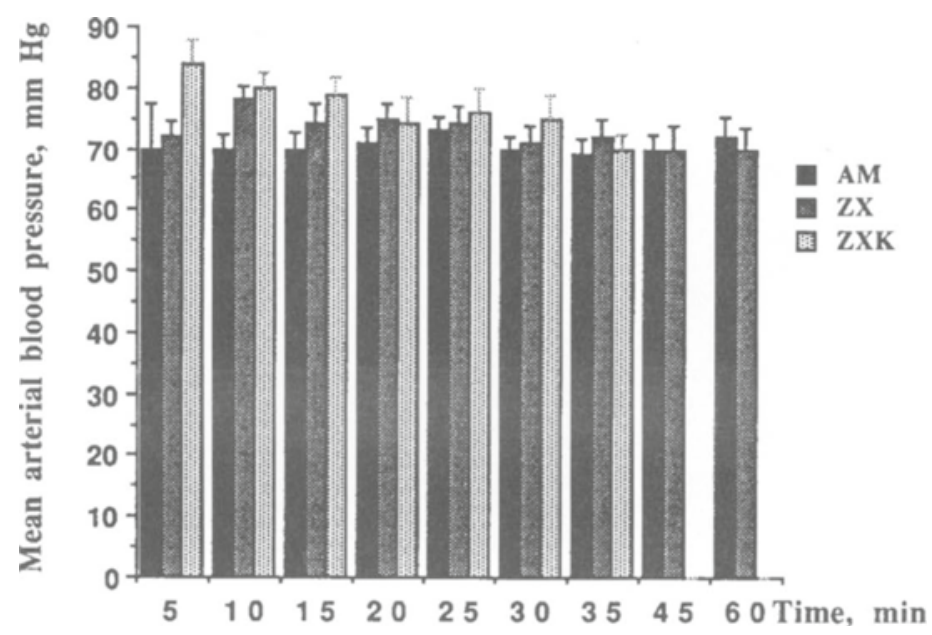

Figure 3. Mean arterial blood pressure monitored in 3 experimental groups of pigs 5, 10, 15, 20, 25, 30, 35, 45 and $60 \mathrm{~min}$ after recumbency. For abbreviations see Fig. 1.

sec, and the small volume that needs to be injected intramuscularly. Induction of anaesthesia with $\mathrm{AM}$ is safe but requires more handling of the animals than ZX, since metomidate must be administered by the intraperitoneal or intravenous route. For proper induction, the pigs also have to be kept in an environment with little disturbance. In contrast to the results obtained in potbellied pigs by Ko et al. (1992), the ZXK-drug combination Zoletil ${ }^{\circledR}$, xylazine and ketamine failed to give proper induction of anaesthesia in 5 pigs out of 7. This may be explained by the fact that growing crossbreeds can respond different to anaesthetics than fullgrown potbellied pigs. The injection of ZXK resulted in a chemical restraint with continuous movements and mild excitement.

The induction, muscle relaxation and recovery were judged to be good after injection of AM or ZX. However, the analgetic effect of both combinations was only considered to be of fair quality. Nevertheless, the results ob- tained in our study clearly show that the combination of Zoletil and xylazine can be used in pigs to produce satisfactory general anaesthesia for minor procedures, but it is recommended that the pigs should be intubated and that the anaesthesia be maintained with additional injectable or inhalation anaesthetic agents during prolonged anaesthesia and advanced surgery. The anaesthesia after administration of ZXK was only judged as fair. Further, the considerably shorter duration of anaesthesia with ZXK could be explained by a lower total dose of the cyclohexamines tiletamine and ketamine as compared with the dose of tiletamine in the ZX combination. Recently, and during the course of our investigation, Ko et al. (1993) reported that approximately 4 times higher doses of tiletamine, zolazepam, xylazine and ketamine, compared with those previously administered to potbellied pigs (Ko et al. 1992), produced similar anaesthesia to a combination of tiletamine, zolazepam and xylazine in swine. They further 
concluded that ZXK had no advantage over $\mathrm{ZX}$ and that the ZXK-drug combination is more laborious to handle. Thus, the variation in response in relation to the administered dose is possibly explained by the use of different breeds.

Both the heart rate, arterial blood pressure and respiratory rate were well maintained during anaesthesia with AM. A marked and persistent tachycardia was noted after induction with ZX and ZXK. This response is probably caused by a central sympathetic nervous stimulation, which is well known after administration of cyclohexamines. Premedication with atropine given to all pigs could partly be responsible for the tachycardia during anaesthesia with ZX and ZXK, but no cardiovascular effects from atropine were registered during anaesthesia with AM. Despite the increase in heart rate, the mean arterial blood pressure did not differ from that in anaesthesia with AM. The significantly higher respiratory rate observed after administration of ZX and ZXK, compared with AM, is characteristic for cyclohexamines (Short 1987). The higher total dose of cyclohexamines in ZX than in ZXK is probably responsible for the difference in respiratory rate between these drug combinations. Also, a high respiratory rate at the expense of a decreased tidal volume has been shown in other species (Short 1987). The decrease in rectal temperature was most pronounced during anaesthesia with $\mathrm{AM}$ and least with ZXK. The lack of body hair and the peripheral vasodilation of the cutaneous vessels, especially after sedation with azaperone, is probably responsible for the hypothermia during anaesthesia in pigs.

The drug combination AM has been reported to produce a basal narcosis with limited analgesia for surgery (Hall \& Clarke 1991), while dissociative anaesthesia with ketamine or tiletamine in combination with proper sedation and muscle relaxation has been regarded as a light general anaesthesia sufficient for surgical manipulation in pigs (Thurmon et al. 1988b). The response to pain, observed as body movements following the pin-prick test or surgical stimulation, was similar during anaesthesia with AM and ZX. Thus, and somewhat unexpectedly, both the present and a previous report by Henrikson (1992) do not indicate that cyclohexamines combined with sedatives results in less response to pin-prick or surgery compared with AM. Mild responses to pin-prick or surgery were observed, but did not result in a simultaneous increase in arterial blood pressure. Although it is difficult to evaluate the quality of analgesia from this study, we decided, based on the criteria of Thurmon et al. (1988a), to describe analgesia as fair in these groups. The ZXKdrug combination failed to produce sufficient analgesia in the present study. A very distinct response to the pin-prick test was seen in the pigs, and surgery was not carried out in this group.

The question of whether the analgesia produced by AM or ZX is sufficient for surgery or whether additional sedation or local analgesia are necessary to enable surgery to be carried out still remains to be answered. Further evaluation of analgesia requires monitoring of the CNS by EEG after a painful stimulus (Forslid 1987, on Waldmann et al. 1994). However, with this limitation in mind it is concluded from the present study that ZX did not provide a superior anaesthesia and analgesia compared to $\mathrm{AM}$ in crossbreed pigs.

In this study, the recovery from all drug combinations was good, as judged by the criteria of Thurmon et al. (1988a). The pigs should be provided with a calm, warm and comfortable environment during recovery. Thus, it is advisable to use a heating pad or heating lamp during prolonged anaesthesia to prevent a fall 
in temperature during the recovery period. The use of dissociative anaesthesia without sufficient sedation will greatly enhance the risk of struggling during recovery.

In conclusion, the present study has shown that AM produces anaesthesia with good cardiovascular stability. It is also an economically favourable drug combination that is suitable for minor surgery. The ZX combination produces a good, reliable and rapid induction and fair anaesthesia, but is more expensive. Good cardiovascular function is maintained, and the laryngeal relaxation makes intubation possible. These characteristics are very useful for induction of anaesthesia in a laboratory environment, as easy handling to avoid stress is necessary for the further research.

\section{References}

Beglinger $R$, Becker $M$, Eggenberger ME, Lombard $C$ : Das Göttinger Miniaturschwein als Versuchtier, (Göttingen Minipigs as laboratory animals). Res. exp. Med. 1975, 165, 251-263. (In German).

Braun W Jr: Anaesthetics and surgical techniques useful in the potbellied pig. Vet. Med. 1993, 5, 441-447.

Eikelenboom G., Minkema D: Prediction of pale, soft, exudative muscle with a non-lethal test for the halothane-induced porcine malignant hyperthermia syndrome. Neth. J. vet. Sci. 1974, 99, 421-426.

Forslid A: Transient, neocortical, hippocampal and amygdaloid EEG silence induced by one minute inhalation of high concentration $\mathrm{CO}_{2}$ in the swine. Acta physiol. scand. 1987, 130, 1-10.

Hall LW, Clarke $K W$ : Anaesthesia of the pig. In: Hall LW, Clarke KW (eds.): Veterinary Anaesthesia, 8th edition, Bailliere Tindall, London, 1983, pp. 287-304.

Hall LW, Clarke KW: Anaesthesia of the pig. In: Hall LW, Clarke KW (eds.): Veterinary Anaesthesia, 9th edition, Baillliere Tindall, London, 1991, pp. 275-289.

Hastings AB, White FC, Sanders TM, Bloor CM: Comparative physiological responses to exercise stress. J. Appl. Physiol.: Respirat. Environ. Exercise Physiol. 1982, 2, 1077-1083.
Henrikson H: Anestesimetoder på smågrisar. (Methods of anaesthesia in growing pigs). Faculty of Vet. Med., Uppsala, Sweden, 1992.

Häggendahl J, Jönsson L, Johansson G, Bjurström S, Carlsten J: Disordered catecholamine release in pigs susceptible to malignant hyperthermia. Pharmacol. Toxicol. 1988, 63, 257-261.

Jensen-Waern $M$, Nyberg L: Valuable indicators of physical stress in porcine plasma. J. vet. Med. 1993, A 40, 321-327.

Ko JCH, Thurmon JC, Benson JG, Tranquilli WJ, Olsen WA: Potbellied pigs anesthetic management and anaesthetics. Vet. Surg. 1992, 21, 6.

Ko JCH, Williams BL, Smith VL, McGrath, CJ, Jacobson JD: Comparison of Telazol, Telazol-Ketamine, Telazol-Xylazine, and Telazol-KetamineXylazine as chemical restraint and anesthetic induction combination in swine. Lab. Anim. Sci., 1993, 43, 476-480.

Muir WW III, Hubbell JAE, Skarda R: Handbook of Veterinary Anaesthesia. St Louis, The C.V. Mosby Company, USA, 1989.

Raekallio M: Sedering och anestesi för gris (Sedation and anaesthesia of the pig) In: Kaartinen L, Mero M, Raekallio M, Räihä J, Sandholm M (eds): Anestesiologi för veterinärer, (Anestesiology for veterinarians), Jyväskylä, Gummers Printing, Finland, 1991, pp. 215-218.

Short CE: Dissociative anesthesia. In: Short CE (ed.): Principles \& Practice of veterinary anaesthesia. Williams \& Wilkins, Baltimore, USA, 1987, pp. 158-169.

Thurmon JC, Benson JG: Special anesthesia considerations of swine. In: Short (ed.): Principles \& Practice of veterinary anaesthesia. Williams \& Wilkins, Baltimore, USA, 1987, pp. 308-322.

Thurmon JC, Benson JG, Tranquilli WJ, Olsen WA: The anaesthetic and analgesic effects of Zoletil and xylazine in pigs: Evaluating clinical trials. Vet. Med. 1988a, 83, 841-845.

Thurmon JC, Benson JG, Tranquilli WJ, Olsen WA, Tracy $\mathrm{CH}$ : Clinical evaluation of the anesthetic effects of tiletamine-zolazepam and xylazine in experimental swine. Vet. Surg. 1988b, 17, 176-177.

Webb A J, Carden A E, Smith, C, Imlah P: 2nd World Congress on Genetics Applied to Livestock Production V, Madrid, 1982, pp. 588.

Von Waldmann K-H, Otto K, Bollwahn W: Ferkelkastration-Schmerzempfindung und Schmerzausschaltung. (Castration of piglets - Pain Sensibility and Anaesthesia). Dtsch. tierärztl. Wschr. 1994, 101, 105-109. 


\section{Sammanfattning \\ En jämförande studie a olika anestetika id allmän anestesi på äxande grisar.}

Denna försöksstudie är gjord med utgångspunkt från 2 olika användningsområde för allmän anestesi på gris. A) anestesi för kirurgi under fältmässiga förhållande och $\mathrm{B}$ ) anestesi med längre duration för experimentell kirurgi. Djuren delades in i 3 olika försöksgrupper. En grupp sövdes med azaperon (Stresnil ${ }^{\circledR}$ ) och metomidat (Hypnodil ${ }^{\circledR}$ ), en grupp med Zoletil ${ }^{\circledR} \mathrm{i}$ kombination med xylazin (Rompun ${ }^{\circledR}$ ) och den sista gruppen med Zoletil ${ }^{\circledast}$, xylazin och ketamin $\left(\right.$ Vetalar $\left.^{\circledR}\right)$.

Följande parametrar undersöktes på varje gris: hjärtfrekvens, andningsfrekvens, blodtryck med blodtrycksmanschett, anestesidjup och temperatur.

Anestesikvaliteten och anestesidjupet mättes med hjälp av grisens svar på smärtsamma stimuli såsom nyp i kronrand, svans och hud med pincett. Mindre omfattande kirurgi med samtidig blodtrycksmätning utfördes på åtta grisar för att kunna utvärdera om sambandet mellan smärtsamt stimuli och reaktion hos grisen åtföljdes av blodtrycksstegring. Inget klart samband kunde noteras.

Av de i studien ingående anestesikombinationerna fungerar azaperon och metomidate samt Zoletil $^{\circledR}$ och xylazin likvärdigt för kirurgi under fältmässiga förhållanden. Båda kombinationerna ger en god induktion, bra muskelavslappning och bra uppvaknande ur anestesin. Den analgetiska effekten är emellertid svårbedömd, men torde vara tillfyllest för mindre kirurgi. För närvarande ställer sig alternativet $A M$ mer fördelaktigt ur ekonomisk synvinkel. För användning inom experimentell kirurgi med längre tids anestesi är det bästa alternativet Zoletil ${ }^{\otimes}$ och xylazin. Denna kombination ger snabb och tillförlitlig induktion av anestesi, är lätt att administrera då volymen är liten och allt injiceras intramuskulärt. Intubering kan med lätthet genomföras efter induktion med ZX och därefter kan anestesi med inhalation av t.ex halothan eller isofluran användas för underhåll.

(Recei ed No ember 4, 1994; accepted May 24, 1995).

Reprints may be obtained from: G. Nyman, Department of Medicine and Surgery, Faculty of Veterinary Medicine, Swedish University of Agricultural Sciences, P.O. Box 7037, S-750 07 Uppsala, Sweden. 
